Jurnal Keperawatan Silampari

Volume 4, Nomor 1, Desember 2020

e-ISSN: 2581-1975

p-ISSN: 2597-7482

DOI: https://doi.org/10.31539/jks.v4i1.1604

\title{
PENURUNAN BERAT BADAN PADA REMAJA OBESITAS MENGGUNAKAN HIPNOTERAPI
}

\author{
Maria Tarisia Rini ${ }^{1}$, Bangun Dwi Hardika ${ }^{2}$, Ketut Suryani ${ }^{3}$ \\ Universitas Katolik Musi Charitas ${ }^{1,2,3}$ \\ tarisia_rini@ukmc.ac.id ${ }^{1}$
}

\begin{abstract}
ABSTRAK
Penelitian ini bertujuan untuk mengetahui pengaruh hipnoterapi terhadap penurunan berat badan pada remaja obesitas. Desain penelitin yang digunakan adalah quasi experiment. Hasil penelitian didapatkan 15 responden $(68.2 \%)$ mengalami penurunan berat badan dan 7 responden $(31.8 \%)$ tidak mengalami penurunan berat badan. Dari hasil uji statistik didapatkan nilai $\mathrm{p}$ value 0.001 dengan nilai koefisien korelasi 0.682 . Selain itu $\mathrm{p}$ value hasil uji chi square 0.004. Simpulan, ada hubungan yang signifikan antara hypnoterapi dengan penurunan berat badan.
\end{abstract}

Kata kunci: Berat Badan, Hipnoterapi, Remaja

\section{ABSTRACT}

This study aims to determine the effect of hypnotherapy on weight loss in obese adolescents. The research design used is a quasi-experiment. The results showed that 15 respondents (68.2\%) experienced weight loss, and seven respondents (31.8\%) did not experience weight loss from the statistical test results obtained p-value 0.001 with a correlation coefficient value of 0.682. Also, the p-value of the chi-square test results is 0.004. In conclusion, there is a significant relationship between hypnotherapy and weight loss.

Keywords: Weight Loss, Hypnotherapy, Youth

\section{PENDAHULUAN}

Angka kejadian obesitas pada remaja terus mengalami peningkatan. Hal tersebut terlihat dari angka kejadian obesitas anak usia 2-19 pada tahun 2017 mengalami peningkatan 0,8\% dari tahun sebelumnya. Angka kejadian obesitas pada anak usia 2-19 tahun di tahun 2015-2016 sebesar 18,5\% dan meningkat menjadi 19,3\% di tahun 20172018 (Hales et al., 2020; The State of Obesity, 2018).

Remaja yang mengalami obesitas jika tidak dilakukan penanganan yang tepat berdampak pada resiko penyakit kardiovaskular seperti hipertensi, gangguan jantung dan metabolik gangguan ginjal, kanker serta berpotensi menganggu hubungan sosial yang dapat membuat remaja mengalami kemunduran perkembangan baik secaramental dan emosi.

Berbagai upaya dilakukan untuk menurunkan berat badan dan mempertahankannya. Salah satu terapi komplementer yang dapat digunakan untuk menurunkan berat badan diantaranya yaitu dengan hypnoterapi. Hipnoterapi adalah pemberian sugesti positif untuk mengendalikan alam bawah sadar (Kihlstrom, 2018). 
Penatalaksanaan obesitas pada anak memerlukan kerjasama dan keterlibatan seluruh anggota keluarga. Prinsip penatalaksanaannya harus tetap mempertimbangkan faktor tumbuh kembang yang masih terus berlangsung sampai masa remaja. Penatalaksanaan terapi hipnosis pada keluarga didampingi oleh perawat sehingga implementasi terapi ini yang ditujukan untuk menurunkan berat badan anak dan juga meningkatkan kualitas hidup anak dengan optimalisasi tumbuh kembang anak tanpa risiko kesehatan yang diakibatkan masalah obesitas di masa yang akan datang (Darmawati, 2017).

Hipnoterapi telah banyak diteliti efektivitasnya dalam menurunkan berat badan. Penelitian tersebut diantaranya dilakukan oleh Bo et al., (2018) menunjukkan bahwa tidak ada pengaruh self-hypnosis antara kelompok control dengan kelompok intervensi. Namun dari hasil penelitian tersebut terlihat bahwa kelompok intervensi yang melakukan selfhypnosis secara teratur mengalami penurunan berat badan yang lebih tinggi dibandingkan dengan kelompok control. Selain itu, kelompok intervensi juga memiliki kualitas hidup yang lebih baik.

Hasil penelitian Levenson \& David (2018) didapatkan hasil tidak ada perbedaan anntara kelompok ahli diet dengan kelompok self-hypnosis. Meskipun tidak ada perbedaan antar kedua kelompok, namun jika dilihat dari rerata penurunan berat badan. Kelompok self-hypnosis mengalamai penuruan berat badan $(5,2$ pound atau $2,36 \mathrm{~kg})$ lebih banyak jika dibandingkan dengan kelompok yang melakukan diet dengan pengawasan ahli diet (3,7 pound atau 1,68 kg). Dari hasil penelitian ini juga didapatkan hasil bahwa ada perbedaan penurunan level A1c antara kelompok diet dan kelompok self-hypnosis.

Hasil survei awal pada bulan Agustus tahun 2019 yang dilakukan terhadap remaja disalah satu SMP swasta Palembang saat dilakukan pemeriksaan antropometri dengan pengukuran berat badan dan tinggi badan dari 55 siswa dan siswi terdapat 51siswa dan siswi yang mengalami obesitas berdasarkan hasil niai z-score $>2$ SD. Mereka mengatakan belum pernah melakukan teknik hipnoterapi untuk menurunkan berat badan.Tujuan penelitian ini untuk mengetahui pengaruh hipnoterapi terhadap penurunan berat badan pada remaja obesitas di SMP Palembang.

Hipnoterapi merupakan pemberian sugesti positif yang bersifat permanen sehingga mampu menjaga pola makan remaja. Penelitian sebelumnya menjelaskan teknik hipnosis dengan kelompok diet dan tentang pelaksanaan terapi hipnosis, aktivitas fisik serta nutrisi. Namun pada penelitian ini berfokus pada sugesti yang diberikan pada responden yaitu mengurangi porsi nasi dan cemilan, dengan demikian anak dapat mempertahankan pola makan sehat dan berat badannya tanpa menggunakan obat-obatan dan diet yang dapat menyiksa. Hipnoterapi ini sangat aman dan tidak menimbulkan dampak yang nagatif.

\section{METODE PENELITIAN}

Penelitian ini dilakukan di tiga SMP Swasta di Kota Palembang. Pengambilan data dilakukan pada 09 Agustus s.d 15 Agustus 2020. Sampel dalam penelitian adalah remaja yang mengalami obesitas. Teknik pengambilan sampel yang digunakan adalah purposive sampling. Penelitian dilakukan door to door selama 1 minggu, setiap responden diberikan hipnoterapi selama 20 menit per sesi, kemudian dilakukan penimbangan. 


\section{HASIL PENELITIAN}

Tabel. 1

Distribusi Usia Responden

\begin{tabular}{cccc}
\hline Usia Responden & Usia Paling Muda & Usia Paling Tua & Median \\
\hline Usia & 13 tahun 1 bulan & 16 tahun 7 bulan & 14.75 \\
\hline
\end{tabular}

Berdasarkan tabel 1 distribusi usia responden dalam penelitian adalah 13 tahun 1 bulan dan usia paling tua 16 tahun 7 bulan.

Tabel. 2

Distribusi Jenis Kelamin dan Penurunan Berat Badan Responden Penelitian

\begin{tabular}{lcc}
\hline Variabel & $\mathrm{f}$ & $\%$ \\
\hline Jenis Kelamin & 7 & 31.8 \\
Laki-laki & 15 & 68.2 \\
Perempuan & & \\
\hline Berat Badan & 7 & 31.8 \\
Tidak menurun & 15 & 68.2 \\
Menurun & 22 & 100.0 \\
\hline Total & & \\
\hline
\end{tabular}

Berdasarkan tabel 2 distribusi jenis kelamin responden penelitian mayoritas adalah perempuan sebanyak 15 responden atau $68.2 \%$, dan mayoritas responden 15 diantaranya mengalami penurunan berat badan atau $68,2 \%$.

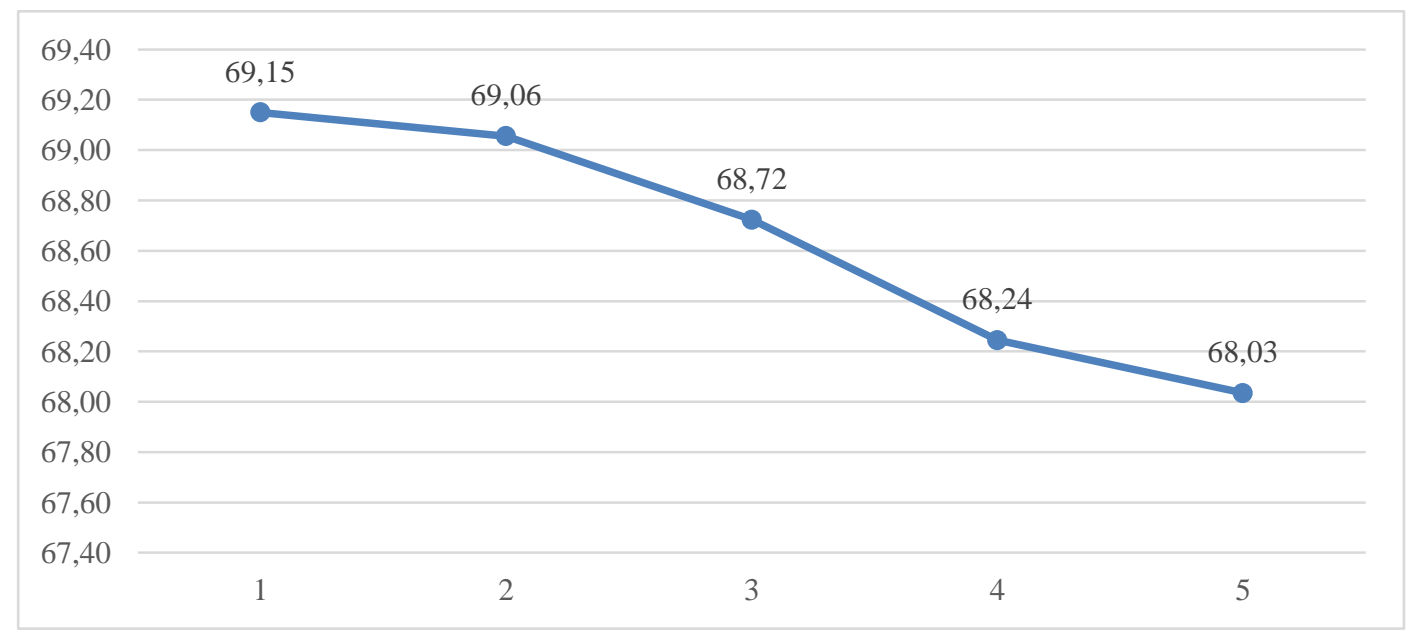

Grafik. 1

Grafik Penurunan Berat Badan Responden yang Dilakukan Terapi Hypnoterapi dari Rata-Rata Pengukuran Berat Badan Setelah Pertemuan

Berdasarkan grafik 1 rata-rata pengukuran berat badan tiap pertemuan pada saat sebelum dilakukan hypnoterapi dan setiap pertemuan setelah diberikan terapi serta pada pertemuan terahir saat evaluasi didapatkan selisih hasil penurunan berat badan sebesar $1.12 \mathrm{~kg}$. 
Tabel. 3

Hasil Uji Korelasi Berat Badan Kelompok Kontrol dan Kelompok Hypnoterapi

\begin{tabular}{lcccccccc}
\hline \multirow{2}{*}{ Kelompok } & \multicolumn{9}{c}{ Perubahan Berat Badan } & \multirow{2}{*}{-value } & \multirow{2}{*}{ Tidak menurun } & \multicolumn{2}{c}{ Menurun } & Total & & \\
\cline { 2 - 7 } & $\mathrm{f}$ & $\%$ & $\mathrm{f}$ & $\%$ & $\mathrm{f}$ & $\%$ & & \\
\cline { 2 - 8 } Kontrol & 7 & 100 & 4 & 26.7 & 11 & 50 & \multirow{2}{*}{0.004} & \multirow{2}{*}{0.683} \\
Hypnoterapi & 0 & 0 & 11 & 73.3 & 11 & 50 & & \\
\hline Total & 7 & 100 & 15 & 100 & 22 & 100 & & \\
\hline
\end{tabular}

Berdasarkan tabel 3 menunjukkan bahwa distribusi responden pada kelompok kontrol dengan penurunan berat badan sebanyak 4 responden $(26,7 \%)$ dan distribusi pada kelompok terapi hypnoterapi yang mengalami penurunan berat badan sebanyak 11 responden $(73,3 \%)$ dari data distribusi tersebut semua responden dalam keolompok terapi mengalami penurunan berat badan. Nilai p $0.001(<0.05)$ yang artinya ada perbedaan yang bermakna antara berat badan pada kelompok kontrol dan kelompok hypnoterapi dengan. Selain itu jika dilihat dari nilai $r=0.683$ menunjukan bahwa adanya hubungan yang kuat antara hypnoterapi dengan penurunan berat badan sebelum dan sesudah diberikan terapi tersebut.

Tabel 4

Hasil Uji Komparasi Kelompok Hypnoterapi dan Kontrol

\begin{tabular}{lcccc}
\hline & Median & Min-max & $\mathrm{X}^{2}$ & p-value \\
\cline { 1 - 3 } Kontrol & 68.2 & $61.00-80.30$ & \multirow{2}{*}{10.267} & \multirow{2}{*}{0.002} \\
\hline Hypnoterapi & 66.6 & $61.00-74.40$ & & \\
\hline
\end{tabular}

Berdasarkan tabel 4 menunjukkan bahwa pada kelompok kontrol nilai median berat badan responden dalam penelitian ini adalah 68.2. Nilai p $0.002(<0,025)$ artinya ada pengaruh yang bermakna antara terapi hypnoterapi terhadap penurunan berat badan remaja obesitas.

\section{PEMBAHASAN}

Dalam penelitian ini didapatkan hasil bahwa hypnoterapi memiliki pengaruh terhadap penurunan berat badan pada anak obesitas. Hasil penelitian yang dilakukan oleh Bo et al., (2018) tidak ada pengaruh self-hypnosis antara kelompok control dengan kelompok intervensi. Namun dari hasil penelitian tersebut terlihat bahwa kelompok intervensi yang melakukan self-hypnosis secara teratur mengalami penurunan berat badan yang lebih tinggi dibandingkan dengan kelompok control. Selain itu, kelompok intervensi juga memiliki kualitas hidup yang lebih baik.

Penatalaksanaan obesitas pada anak memerlukan kerjasama dan keterlibatan seluruh anggota keluarga. Prinsip penatalaksanaannya harus tetap mempertimbangkan faktor tumbuh kembang yang masih terus berlangsung sampai masa remaja. Penatalaksanaan terapi hipnosis pada keluarga didampingi oleh perawat sehingga implementasi terapi hipnosis yang ditujukan untuk menurunkan berat badan anak dan juga meningkatkan kualitas hidup anak dengan optimalisasi tumbuh kembang anak tanpa risiko kesehatan yang diakibatkan masalah obesitas di masa yang akan datang. Penerapan ketiga terapi ini didahului dengan promosi kesehatan terkait gizi dan aktifitas fisik yang dibutuhkan oleh anak usia sekolah yang obesitas. Selanjutnya anak usia sekolah diberikan 
penjelasan dan demonstrasi self hypnosis untuk meningkatkan motivasi meningkatkan aktifitas fisik dan pengelolaan nutrisi. Dalam self hypnosis anak diminta berada dalam kondisi rileks, memejamkan mata dan membayangkan bentuk tubuh ideal yang diharapkan anak setiap sebelum tidur dan saat bangun tidur. Selanjutnya anak diminta melakukan hipnosis terhadap diri sendiri dengan sering sering mengucapkan pada diri sendiri: 1. Makan sayur dan buah membuat tubuh sehat dan kuat 2. Kebanyakan makan yang manis dan berminyak adalah racun bagi tubuh saya, 3. Saya akan beraktivitas sampai berkeringat agar sehat (Darmawati, 2017).

Penelitian yang dilakukan Sundari (2016) menemukan bahwa selfefficacy pada remaja memiliki hubungan kuat yang signifikan terhadap perilaku diet remaja. Remaja dengan kepercayaan diri yang baik, memiliki kecenderungan berhasil dalam mempraktikan perilaku diet yang sehat. Dalam penelitiannya Sundari juga menemukan bahwa lebih dari separuh remaja hanya memiliki kepercayaan diri yang cukup untuk melakukan diet sehat. Pernyataan diatas didukung oleh penelitian lain yang menunjukan bahwa ada hubungan antara body image dengan kepercayaan diri. Untuk mencapai kepercayaan diri yang baik remaja ingin meningkatkan body imagenya. Namun di sisi lain, remaja memutuhkan kepercayaan diri untuk melakukan diet, sehingga diet yang dilakukan dapat berhasil dan mampu memberikan gambaran diri yang baik (Ifdil et al., 2017).

Hasil penelitian Levenson \& David (2018) tidak ada perbedaan anntara kelompok ahli diet dengan kelompok self-hypnosis. Meskipun tidak ada perbedaan antar kedua kelompok, namun jika dilihat dari rerata penurunan berat badan. Kelompok self-hypnosis mengalamai penuruan berat badan $(5,2$ pound atau $2,36 \mathrm{~kg})$ lebih banyak jika dibandingkan dengan kelompok yang melakukan diet dengan pengawasan ahli diet (3,7 pound atau 1,68 kg). Dari hasil penelitian ini juga didapatkan hasil bahwa ada perbedaan penurunan level A1c antara kelompok diet dan kelompok self-hypnosis.

Penelitian yang dilakukan Darmawati (2017) menunjukkan bahwa terapi hipnosis dapat diterapkan dalam proses asuhan keperawatan bagi keluarga binaan perawat dengan tujuan utama perubahan perilaku hidup sehat yang menunjang pada upaya pencapaian berat badan ideal bagi anak dan keluarga dengan masalah obesitas. Pendekatan terapi hipnosis dilakukan untuk memberikan sugesti positif pada anak terkait tubuh ideal dan pola hidup sehat. Penerapan terapi hipnotis ini dapat dijadikan sebagai inovasi perawat puskesmas yang akan melaksanakan kunjungan rumah sehingga dapat mengendalikan angka kejadian obesitas pada anak usia sekolah.

Penelitian yang dilakukan Santoso \& Listywan (2020) menunjukan bahwa terdapat perbedaan yang signifikan pada rerata efikasi diri remaja sebelum dan sesudah intervensi diberikan $(t=-7.400 ; p$-value $=0.001)$. Hal tersebut menunjukan bahwa remaja dapat memiliki efikasi diri untuk melakukan diet sehat yang lebih baik setelah diberikan hipnoterapi.

Keberhasilan hipnoterapi tentu sangat bergantung pada kondisi serta tingkat sugestibilitas induvidu yang diintervensi. Hasil studi menunjukan peningkatan efikasi diri remaja lebih banyak terjadi pada remaja dengan tingkat sugestibilitas yang baik. Remaja yang memiliki efikasi diri rendah sekalipun, jika memiliki tingkat sugestibilitas yang baik akan mudah untuk ditingkatkan efikasi dirinya melalui sesi hipnoterapi. Dalam pelaksanaan sesi hipnoterapi, diberikan penguatan terhadap kemampuan remaja untuk melakukan hal-hal yang dibutuhkan untuk melakukan diet yang sehat. Penguatan diberikan kepada remaja melalui teknik anchoring, yaitu menanamkan sebuah perilaku 
dengan pemicu tertentu. Teknik anchoring dinilai efektif dan dapat menunjukan efek yang cepat dalam merubah perspektif induvidu (Budiman, 2017).

Berbeda dengan penelitian yang dilakukan oleh Levenson \& David (2018) yang menunjukkan bahwa tidak ada perbedaan anntara kelompok ahli diet dengan kelompok self-hypnosis. Meskipun tidak ada perbedaan antar kedua kelompok, namun jika dilihat dari rerata penurunan berat badan. Kelompok self-hypnosis mengalamai penuruan berat badan $(5,2$ pound atau $2,36 \mathrm{~kg}$ ) lebih banyak jika dibandingkan dengan kelompok yang melakukan diet dengan pengawasan ahli diet $(3,7$ pound atau $1,68 \mathrm{~kg})$.

Hal lain yang juga mempengaruhi adalah pola hidup hal ini sangat berpengaruh terhadap kejadian pada obesitas namun masih dapat untuk di modifikasi dengan beberapa cara, baik dengan memperhatikan kebiasaan makan, waktu tidur dan aktivitas fisik yang dibutuhkan harus sesuai usia dan jenis kelamin. Kondisi rendahnya dalam melakukan aktivitas fisik pada anak ialah masalah utama terjadinya berat badan lebih. Dalam memberikan hypnoterapi responden dalam penelitian ini diajak untuk menerima sugesti positif seperti olah raga, dan menjaga pola makan yang sehat.

\section{SIMPULAN}

Ada hubungan yang signifikan antara hypnoterapi dengan penurunan berat badan. Hypnoterapi memiliki pengaruh yang positif terhadap penurunan berat badan remaja obesitas.

\section{SARAN}

Saran untuk remaja dengan obesitas harus mengatur pola makan yang sehat, melakukan aktifitas fisik, dan mengikuti terapi hypnoterapi untuk menurunkan berat badan.

\section{DAFTAR PUSTAKA}

Bo, S., Rahimi, F., Goitre, I., Properzi, B., Ponzo, V., Regaldo, G., Boschetti, S., Fadda, M., Ciccone, G., Daga, G. A., Mengozzi, G., Evangelista, A., De Francesco, A., Belcastro, S., \& Broglio, F. (2018). Effects of Self-Conditioning Techniques (Self-Hypnosis) in Promoting Weight Loss in Patients with Severe Obesity: A Randomized Controlled Trial. Obesity, 26(9), 1422-1429. https://doi.org/http://dx.doi.org/10.1002/oby.22262

Budiman, B. (2017). Efektivitas Hypnoterapi Teknik Anchor terhadap Perubahan Perilaku Merokok Remaja. Psikis: Jurnal Psikologi Islami, 2(2), 135-148. http://jurnal.radenfatah.ac.id/index.php/psikis/article/view/1185

Darmawati, I. (2017). Literatur Review : Aplikasi Terapi HAN (Hipnotis, Aktifitas Fisik, Nutrisi) pada Keluarga Anak Usia Sekolah dengan Obesitas. Jurnal Keperawatan Komprehensif, 3(2), 86. https://doi.org/10.33755/jkk.v3i2.89

Hales, C. M., Carroll, M. D., Fryar, C. D., \& Ogden, C. L. (2020). Prevalence of Obesity and Severe Obesity among Adults: United States, 2017-2018. NCHS Data Brief, no 360. In National Center for Health Statistics (Issue 360). https://www.cdc.gov/nchs/products/index.htm

Ifdil, I., Denich, A. U., \& Ilyas, A. (2017). Hubungan Body Image dengan Kepercayaan Diri Remaja Putri. Jurnal Kajian Bimbingan dan Konseling, 2(3), 107-113. https://doi.org/10.17977/um001v2i32017p107

Kihlstrom, J. F. (2018). Hypnosis as an Altered State of Consciousness. Journal of Consciousness, 25(11-12), 53-72. www.ocf.berkeley.edu 
Levenson, M., \& David, D. (2018). Efficacy of Self-Hypnosis in Type 2 Diabetics with $\mathrm{BMI} \geq 25$ : A Randomized Clinical Trial. Endocrine Practice, 24, 143-144. https://search.proquest.com/docview/2050597752?accountid=25704

Santoso, D. Y. A., \& Listywan, B. (2020). Efektifitas Hipnoterapi terhadap Efikasi Diri Remaja untuk Melakukan Diet Sehat. Jurnal Ilmiah STIKES Kendal, 10(2), 233238. https://doi.org/https://doi.org/10.32583/pskm.v10i2.732

Sundari, V. (2016). Hubungan Citra Raga dengan Perilaku Diet pada Remaja Putri [Universitas Muhammadiyah Malang]. In Thesis. http://eprints.umm.ac.id/id/eprint/29887

The State of Obesity. (2018). Childhood Obesity Trends. Robert Wood Johnson Foundation (RWJF). https://www.stateofobesity.org/childhood-obesitytrends/\%0Ahttps://stateofobesity.org/childhood-obesity-trends/ 